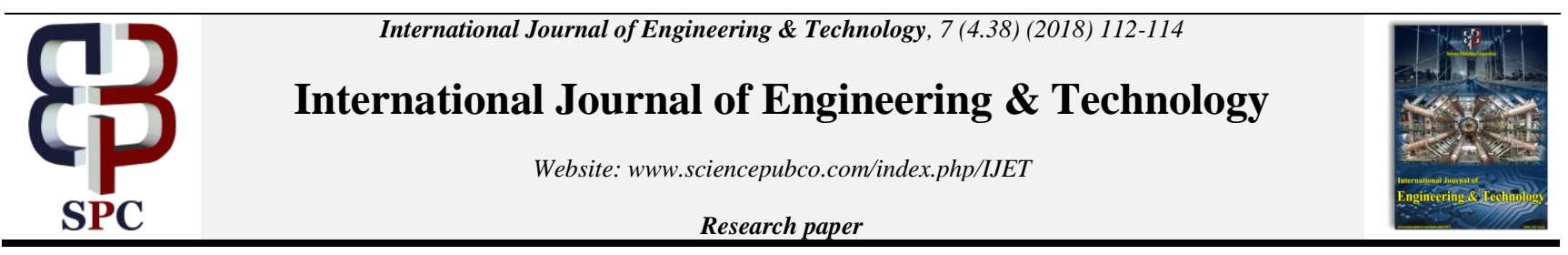

\title{
Modelling Economic Growth Based on Factors of Innovation Production Potential Development
}

\author{
Elena Derunova1, ${ }^{1}$ Sergey Andryushchenko ${ }^{1}$, Vladimir Derunov ${ }^{1}$ \\ ${ }^{1}$ Institute of Agrarian Problems RAS, Moskovskaya str., 94, Saratov, 410012, Russia \\ *Corresponding author E-mail: derunova.el@list.ru
}

\begin{abstract}
The Russian economic growth is associated with the increase in the competitive advantages of the domestic industry and the material sector of economy, including agriculture. The article studies the factors that have positive impact on the economic development and growth, as well as those that restrain these processes. The problem of assessing the need in innovative activity of economic sectors is actualized taking into account the differences of Russian regions in terms of agricultural productivity. The use of the imitations and innovations' theory and methodological instruments of production functions' models is substantiated. Thus, the Solow model is studied, and the improvement of the model, including the funds' introduction delay when the optimal accumulation rates are equal to the elasticity coefficients by funds, is shown. The factors that include various economic growth models: volumes of capital, physical and intellectual labor, labor productivity, the production returns rate, the scientific and technological progress rate, the population growth rate, the consumer demand, production structure, institutional factors, and saving rates, are studied. It is proved that the study of neoclassical models of the economic growth shows their incomplete adequacy taking into account all differentiating factors, competitive processes and differentiating branch structures of economy. In the work, the hypothesis of the interrelationship of the saving rate, labor productivity and the volume of investments in Russia is mathematically proven taking into account the differentiation of Russian regions and peculiarities of statistical accounting.
\end{abstract}

Keywords: Innovations, Economic Growth, Solow Model, Regional Differentiation, Industrial and Agricultural Production, Saving Rate, Labor Productivity, Investment Volume.

\section{Introduction}

One of the fundamental factors of the economic growth and the materials sector, in particular, is the promotion of innovative and high-tech products on the domestic and world markets.

There are a number of reasons that restrain the economic growth. They include [1] the arrears of financial and organizational infrastructures, the lack of developed systems of export support by the state, difficulties in adapting competitive technologies to mass production, insufficient level of the specialized engineering development, low efficiency of production, and rather considerable material consumption of agricultural and industrial products.

The instability of the global economy and the vagueness of its formation prospects, subject to reducing resources, decrease profitability in processing sectors, and complicate the development of the industrial sector of economy.

Today promising innovative technologies that enable developing of new large oil production centers [2] and food production in large companies have become the main areas of the materials sector development.

In general, the growth of economy is associated with the impact of a number of factors: production efficiency, profitability, accumulation rates and investment activity; sectoral and reproduction structure of public products; modification of the absolute size and the relative share of gross domestic product; modification of export and import of raw materials and foreign trade balance.

Based on this, in order to reduce the materials specialization of the economy, it is necessary to modify the attitude towards the resource potential of Russia, to stimulate investments in processing sectors and high-tech industries, and to reduce the flow of capital from the country [3]. To increase export on a qualitative level, it is necessary to increase the share of finished goods [4].

The current actual task of the economy is to solve the problem on assessing the innovation activity of Russian regions. Probably, one of the main reasons of difficulties related to this is the reporting system where enterprises are not interested in displaying their innovative activity. In accordance with the recommended methodology for collecting statistical information when classifying products and referring to them as high-tech products, it is necessary to collect a lot of information, which is quite difficult. It goes not only about expenditures for high-tech products, the number of employees involved in production, but also about the correlation of innovations in terms of technological, marketing or organizational categories with the relevant amount of information. It is easier for enterprises to not display this information at all or to display its minimum. However, state authorities need information about the performed work and the tempo and volume of innovation activity in general [5], because, as a rule, high-tech products are developed by using the budget.

In order to process the information, it is necessary to have methodological instruments that would display and assess the innovation activity of all organizations supported by state regulation. Not only national but also foreign researchers have been interested in this task for a long time. Thus, production functions' models were offered as the first methodological instruments. When improving them, the economic growth models were developed. 


\section{Methods}

One of the most wide-spread models is the R. Solow model characterized by the fact that the rate of labor resources' growth is exogenous, the technological level has a constant index, and the return on two production factors (labor and capital) does not change. A more complex model implies technical progress, too. The next degree of complexity includes models that take into account natural resources. When studying and improving the Solow model, special results were achieved by V.A. Kolemaev [6]. He considered the model in terms of the delay when introducing funds without taking into account the dynamics of the technological progress. Accordingly, he formulated this management task as an accumulation rate in the context of the Solow model.

In order to efficiently assess the impact of innovation activity, it is necessary to make nonlinear multiple regression equations in the form of various multiplicative production functions for statistical estimation of gross domestic product (GDP), gross regional product (GRP), and gross value added (GVA). On the country level, the latter indicator is less than GDP by the difference between food taxes and subsidies. GVA is presented in statistics as the sum of GRP for all regions, in regions - as the sum of the value added formed by sectors of the economy [12]. Due to the variety of natural and climatic conditions, the agrarian sector of Russian regions is characterized by a wide variety of economic indicators. The GVA indicator allows applying the theory that divides the economic growth into two stages: imitative and innovative. The study of innovations' spread shows that in Russia there are regions with large agricultural holdings that start innovations, and regions that directly borrow them [14].

The formation of production functions' models allows making statistical forecasts on the main socio-economic indicators, and ratings of regions by high-tech indicators and the speed of investments use, as well as developing algorithms for the efficient management of accumulation rates (intensity of use).

The Solow model is one of the neoclassical models of the economic growth. Neoclassical models tried to overcome a whole range of possible limitations of Keynesian models and reflect specific characteristics of macroeconomic processes. This model is characterized by the fact that it shows the instability of the dynamic equilibrium of Keynesian models that is the result of the interchangeability of production factors. Instead of the Leontief function, the Cobb-Douglas function where labor and capital are substitutes is used.

According to the Solow model, saving rates are the main factor characterizing the capital-labor ratio and correspondingly reflecting the level of output. States that have a consistently high saving rate are characterized by a developed level of capital-labor ratio, which, in its turn, provides a more rapid rate of economic growth.

Thus, the Solow model is the most important starting point for almost any study related to the economic growth. Using this model, it is possible to define the reasons of temporary and permanent (sustainable) economic growth [7].

\section{Results and Discussion}

Various models of the economic growth that take into account the fundamentally important factors for the formation of the national economy mainly include such factors as the volumes of capital, physical and intellectual labor, labor productivity, the production return rate, the rate of scientific and technological progress, the population growth rate, demand, production structure, institutional factors, saving rates, etc.

Almost all models analyze only consequences for the economic development which are the results of changes in various factors. In addition, today there is no single theoretic and practical model that takes into account another important factor of the interregional differentiation of the economic development. The effect of this factor is mainly substantiated by the state of the sectoral structure of economy and the formation of competitive processes on the sectoral market. It is necessary to note that such models take into account competitive processes not the way they are. Instead they are determined indirectly as a result of their development - the rates of profits economic entities get. It happens while in fact the rates of profit for all entities are different, and the market system is far from standard types - perfect competition, monopolistic competition and oligopoly.

The study of neoclassical models of the economic growth shows that they are not fully adequate taking into account all differentiating factors, competitive processes and differentiating branch structures of the economy.

Neoclassical models of the economic growth make it possible to describe specific features of macroeconomic processes, and to consider the economic growth in terms of interchangeable production factors [8]. The Cobb-Douglas model assumes that, at a certain technological level production volumes depend on the amount of capital and labor used. Nevertheless, the technological level is gradually being improved, and therefore temporary factors are introduced into the equation. Based on the changes taking into account the time factor of Jan Tinbergen, the Cobb-Douglas function will be as follows [9]:

$C_{i}=D_{i} \cdot R_{i}^{\gamma} \cdot A_{i}^{\beta} \cdot V_{i}^{\gamma}$

where

$\mathrm{C}_{\mathrm{i}}$ is the production volumes,

$D_{i}$ is the coefficient that shows the development of the scientific and technological progress,

$\mathrm{R}_{\mathrm{i}}^{\gamma} \cdot \mathrm{A}_{\mathrm{i}}^{\beta} \cdot \mathrm{V}_{\mathrm{i}}^{\gamma}$ are the expenditures of labor, capital and natural resources, and

$\beta, \gamma$ are the indicators of the elasticity of the production by labor, capital and natural resources.

In the context of the above, it is necessary to consider the Solow economic growth model [10]. Thus, for example, Solow introduced an auxiliary variable of labor productivity (C), as well as capital-labor ratio:

$\mathrm{r}=\mathrm{R} / \mathrm{A}$

These variables are related by the following equation:

$\mathrm{C}=\mathrm{g}(\mathrm{r})$

The demand in the Solow model is defined as the aggregate of investments ( $\mathrm{t}$ ) and consumption $(\mathrm{k})$ per unit of labor:

$\mathrm{c}=\mathrm{t}+\mathrm{k}$

Consequently, the consumption can be calculated by using the following formula:

$\mathrm{k}=(1--\mathrm{n}) \mathrm{C}$

where

$\mathrm{n}$ is the saving rates.

To obtain an equality formula on the investment inflow and savings under equal market conditions, it is recommended to substitute the consumption formula and the aggregate demand formula.

$\mathrm{t}=\mathrm{n} \cdot \mathrm{C}$

When adding factors of the innovative development of the production potential to the model, production functions are modified: 
$\mathrm{C}=\mathrm{E}(\mathrm{R}, \mathrm{A}, \mathrm{Q})$

where

$\mathrm{E}$ is the indicator of labor efficiency that depends on the health, education and qualification of employees,

$\mathrm{A}$ and $\mathrm{Q}$ are the number of conventional units of labor of one employee and the number of employees.

The indicators of the capital (r) and labor productivity (c) indexes introduced by Solow are characterized by constant efficiency and are calculated using the following formulas:

$\mathrm{r}=\frac{\mathrm{R}}{\mathrm{A} \cdot \mathrm{Q}} ; \mathrm{c}=\frac{\mathrm{C}}{\mathrm{A} \cdot \mathrm{Q}}$

Therefore,

$\mathrm{n} \cdot \mathrm{c}=(\mathrm{a}+\mathrm{m}+\mathrm{q}) \mathrm{r}$

where a is the population growth rate,

$\mathrm{m}$ is the tempo of technical progress, and

$\mathrm{q}$ is the permanent capital depreciation.

In order to more accurately define the economic growth, the Solow model can be improved as follows:

$\Delta \mathrm{r}=\mathrm{t}-(\mathrm{a}+\mathrm{m}+\mathrm{q}) \mathrm{r}$

This equation can be transformed taking into account the regional differentiation of economy [11]:

$\mathrm{n}_{\mathrm{k}} \cdot\left(\frac{\mathrm{R}_{\mathrm{y}}}{\mathrm{Q}_{\mathrm{y}}}\right)^{\alpha_{\mathrm{y}}}=\left(\mathrm{a}_{\mathrm{y}}+\mathrm{m}_{\mathrm{y}}+\mathrm{q}_{\mathrm{y}}\right)\left(\frac{\mathrm{R}_{\mathrm{y}}}{\mathrm{A}_{\mathrm{y}} \cdot \mathrm{Q}_{\mathrm{y}}}\right)$

$\left(\frac{R_{y}}{Q_{y}}\right)^{\alpha_{y}-1}=\frac{a_{y}+m_{y}+q_{y}}{A_{y} \cdot n_{k}}$

$R_{y}^{\alpha_{y}-1}=A_{y}^{\alpha_{y}-1}\left(\frac{a_{y}+m_{y}+q_{y}}{A_{y} \cdot n_{k}}\right)$

where

$\mathrm{n}_{\mathrm{k}}$ is the saving rates in the $\mathrm{k}$ region,

$\mathrm{y}$ is the serial number of the economy sectors.

In this case the volume of products is calculated as the sum of GVA produced in the regions that pursue conducting imitational or mainly investment policy [12].

\section{Conclusion}

Thus, GVA produced taking into account the sectoral structure and regional differentiation [13] of economic indicators can be determined by using the following formula:

$\sum_{\mathrm{k}=1}^{\mathrm{K}} \sum_{\mathrm{j}=1}^{\mathrm{J}} \mathrm{R}_{\mathrm{yk}}=\sum_{\mathrm{k}=1}^{\mathrm{K}} \sum_{\mathrm{j}=1}^{\mathrm{J}} \mathrm{Q}_{\mathrm{yk}}\left(\frac{\mathrm{a}_{\mathrm{y}}+\mathrm{m}_{\mathrm{y}}+\mathrm{q}_{\mathrm{y}}}{\mathrm{A}_{\mathrm{y}} \cdot \mathrm{n}_{\mathrm{k}}}\right)^{\frac{1}{\alpha_{\mathrm{y}}-1}}$

where

$\mathrm{J}$ is the number of industries in the national economy,

$\mathrm{K}$ is the number of regions in the country.

In the Solow model the dependence of the economy growth rate on the factors of innovative development of the production potential for a country with a developed and regionally differentiated agrarian sector can be fully assessed only taking into account the factor of interregional differences.

Thus, the structural reorganization of the economy sectors that will ensure the growth of innovative factors in the production potential development is based on the formation of not only scientific and intellectual, production and technological factors, but also on geographical competitive advantages.

\section{References}

[1] Acemoglu D, Aghion P, Zilibotti F (2006), Distance to frontier, selection, and economic growth. Journal of the European Economic Association 4(1), 37-74.

[2] Dzhumaeva RA, Mukhutdinova TZ (2012), Upravleniye chelovecheskim kapitalom - strategicheskim faktorom razvitiya innovatsionnoy khozyaystvennoy sistemy [Managing human capital as a strategic factor in the development of the innovative economic system]. Bulletin of Kazan Technological University, 2, 84-88.

[3] Belousov DR (2007), O polozhenii v rossiyskoy ekonomike [On the situation in the Russian economy]. Problems of Forecasting, 3, $21-41$.

[4] Mansurova T (2007), Spetsifika razvitiya syryevogo sektora v rossiyskoy ekonomike [Specificity of the development of the raw materials sector in the Russian economy]. Bulletin of the Kazan Technological University, 5, 189-194.

[5] Sistema natsionalnykh schetov [System of national accounts], Russian Statistical Yearbook (2017). Moscow, Stat.collection Rosstat, 258-311.

[6] Derunova E, Firsova A, Vavilina A et al (2014), The study of the dynamics of innovative development of economy on the endogenous growth through multi-sector extension of the Solow model. Biosciences Biotechnology Research Asia, 11(3), 15811589.

[7] Kolemaev VV (2002), Matematicheskaya ekonomika [Mathematical Economics]. Moscow: Unity-Dana.

[8] Tsaregorodtsev EI (2014), Problemy otsenki innovatsionnoy deyatelnosti regiona [Problems of assessing the innovation activity of the region]. Economics and Management, 2(111), 89-94.

[9] Zhulanov EE (2014), Modelirovaniye razvitiya natsionalnoy sotsialno-ekonomicheskoy sistemy pod vliyaniyem regulirovaniya usloviy vneshneekonomicheskoy deyatelnosti regionalnoy promyshlennosti [Modeling the development of the national socioeconomic system as influenced by regulation of the conditions of foreign economic activity of regional industry]. Economic and Humanities, 4(267), 95-104.

[10]Zhuravleva GP, Smagina VV (2008), Ekonomicheskaya teoriya i politika rynochnoy sistemy khozyaystvovaniya [Economic theory and policy of the market system of management]. Moscow: Finance and Statistics.

[11] Derunova E, Semenov A (2013), Study of the problematic issues of the raw material orientation of the economy: the Dutch disease and its influence on innovative development. World Applied Sciences Journal, 25(9), 1295-1301.

[12] Sidorovich AV (2007), Kurs ekonomicheskoy teorii: obshchiye osnovy ekonomicheskoy teorii. Mikroekonomika. Makroekonomika. Osnovy natsional'noy ekonomiki [The course of economic theory: the general foundations of economic theory. Microeconomics. Macroeconomics. Fundamentals of national economy], 3rd edition, Delo i Servis, Moscow.

[13]Zhulanov EE (2012), Vliyaniye sotsialno-ekonomicheskoy asimmetrii regionov na rezultaty modelirovaniya ekonomicheskogo rosta [Impact of socio-economic asymmetry of regions on the results of economic growth modeling]. Economic Analysis: Theory and Practice, 24(279), 10-20. 